\title{
Seroprevalence and risk factors associated with bovine leukemia virus (BLV) seropositivity in cattle herds from Ecuador
}

\author{
Seroprevalencia y factores de riesgo asociados a la seropositividad al virus de la leucemia bovina (BLV) \\ en explotaciones de producción bovina en Ecuador
}

Seroprevalência e fatores de risco associados à soropositividade do vírus da leucemia bovina (BLV) em rebanhos bovinos do Equador

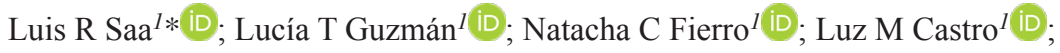 \\ Fabián Reyes-Bueno $^{l}$ (D);Alfonso Carbonero ${ }^{2}$ (D).
}

\begin{abstract}
${ }^{1}$ Departamento de Ciencias Biológicas, Titulación de Ingeniería Agropecuaria, Universidad Técnica Particular de Loja, Ecuador.
${ }^{2}$ Departamento de Salud Animal, Universidad de Córdoba, Campus de Excelencia Internacional Agroalimentario ceiA3, España.
\end{abstract}

To cite this article:

Saa LR, Guzmán LT, Fierro NC, Castro LM, Reyes-Bueno F, Carbonero A. Seroprevalence and risk factors associated with bovine leukemia virus seropositivity in cattle herds from Ecuador. Rev Colomb Cienc Pecu 2021; 34(3): 177-188. DOI: https://doi.org/10.17533/udea.rccp.v34n3a01

\begin{abstract}
Background: Bovine leukemia virus (BLV) is the causative agent of enzootic bovine leukosis (EBL). This disease mainly affects cattle, causing severe economic losses to producers. Objective: To establish individual and herd seroprevalence and determine the risk factors associated with BLV seropositivity for dairy and dual-purpose cattle herds in Ecuador. Methods: A total of 2,668 serum samples from 386 herds were collected. A questionnaire, including variables related to cattle health, management and the environment was completed by each herd. A commercial blocking enzyme-linked immunosorbent assay (ELISA) test was used to determine seropositivity. A generalized estimating equation model (GEE) was developed to determine the factors associated with BLV seropositivity. Results: Individual seroprevalence of BLV infection in Ecuador was $17.3 \%$ $\left(\mathrm{CI}_{95 \%}=15.86-18.74 \%\right)$. Herd prevalence was $37.8 \%\left(\mathrm{CI}_{95 \%}=33.0-42.6 \%\right)$, and intra-herd prevalence ranged between 12.5 and $100 \%$ (median: $37.5 \%$ ). The risk factors associated with BLV seropositivity were artificial insemination $\left(\mathrm{OR}: 2,215 ; \mathrm{CI}_{95 \%}=\right.$ 1.402-3.501), concrete floors (OR: 2.178; $\left.\mathrm{CI}_{95 \%}=1.217-3.889\right)$, presence of wild ruminants $\left(\mathrm{OR}: 2.998 ; \mathrm{CI}_{95 \%}=1.788-5.027\right)$,
\end{abstract}

Received: April 6, 2020; accepted: July 17, 2020

*Corresponding author. San Cayetano Alto SN Av. Marcelino Champagnat CP 1101608, Ecuador. Tel.: +59373701444. Email: 1rsaa@utpl.edu.ec 
and sampling season (wet; OR: $1.996 ; \mathrm{CI}_{95 \%}=1.140-3.497$ ). Conclusions: Results indicate that BLV is widespread in cattle herds in Ecuador. In addition, the study suggests that a control program to fight BLV infection should focus on controlling the risk factors identified.

Keywords: BLV; bovine leukemia virus; cattle; cows; EBL; enzootic bovine leukosis; epidemiology; prevalence; risk factors; ruminant; seroprevalence; seropositivity; virus.

\section{Resumen}

Antecedentes: El virus de la leucosis bovina (BLV) es el principal agente etiológico causante de la leucosis enzoótica bovina (EBL). Esta enfermedad afecta a los bovinos causando grandes pérdidas económicas a los productores. Objetivo: Establecer la seroprevalencia y dispersión del BLV, así como los factores de riesgo asociados a la seropositividad en explotaciones lecheras y de doble propósito en Ecuador. Métodos: Se recolectó un total de 2.668 muestras de suero de 386 explotaciones. Se aplicó un cuestionario que incluyó variables relacionadas con la salud del hato, medidas de manejo, y características ambientales de cada explotación. Para los análisis serológicos se utilizó un test inmunológico ligado a enzimas (ELISA). Para definir los factores de riesgo asociados a la seropositividad a BLV se desarrolló un modelo utilizando ecuaciones de estimación generalizadas (GEE). Resultados: La seroprevalencia de BLV en Ecuador fue de 17,3\% $\left(\mathrm{IC}_{95 \%}=15,86-18,74 \%\right)$. La dispersión fue de 37,8\% $\left(\mathrm{IC}_{95 \%}\right.$ $=33,0-42,6 \%$ ), y la prevalencia intra-hato alcanzó rangos entre 12,5-100\% (media: 37,5\%). Los factores de riesgo asociados a la seropositividad a BLV fueron: inseminación artificial (OR: 2,215; $\left.\mathrm{IC}_{95 \%}=1,402-3,501\right)$, piso de concreto $\left(\mathrm{OR}\right.$ : 2,$178 ; \mathrm{IC}_{95 \%}$ $=1,217-3,889)$, presencia de rumiantes salvajes (OR: 2,998; $\left.\mathrm{IC}_{95 \%}=1,788-5,027\right)$, y temporada de muestreo (húmeda; OR: 1,$\left.996 ; \mathrm{IC}_{95 \%}=1,140-3,497\right)$. Conclusiones: Los resultados indican que el BLV se encuentra disperso en las explotaciones de Ecuador. Adicionalmente, se sugiere la implementación de un programa de control para la lucha contra el BLV, debiéndose considerar medidas que se enfoquen al control de los factores de riesgo identificados en esta investigación.

Palabras clave: BLV; bovinos; EBL; epidemiología; factores de riesgo; ganado; leucosis enzoótica bovina; prevalencia; rumiante; seroprevalencia; seropositividad; virus; virus de la leucemia bovina.

\section{Resumo}

Antecedentes: O vírus da leucemia bovina (BLV) é o principal agente causador da leucose enzoótica bovina (EBL). Esta doença afeta o gado causando graves prejuízos econômicos aos produtores. Objetivo: Estabelecer a soroprevalência e dispersão do BLV, assim como os fatores de risco associados à soropositividade nas produções leiteiras e de duplo propósito no Equador. Métodos: Um total de 2.668 amostras de soro de 386 explorações foram coletadas. Foi aplicado um questionário que incluía variáveis relacionadas à saúde do rebanho, medidas de manejo e ambiente para cada exploração. Para a análise sorológica foi utilizado um teste imunológico sobre enzimas (ELISA) para determinação da soropositividade. Para definir os fatores de risco associados à soropositividade a BLV, foi utilizado um modelo de equações estimativas generalizadas (GEE). Resultados: A soroprevalência de BLVno Equador é de 17,3\% $\left(\mathrm{IC}_{95 \%}=15,86-18,74 \%\right)$. La dispersão de 37,8\% $\left(\mathrm{IC}_{95 \%}=33,0-42,6 \%\right)$, e a prevalência intra-rebanho alcançou entre 12,5-100\% (media: 37,5\%). Os fatores de risco associados à soropositividade a BLV foram inseminação artificial (OR: 2,215; $\left.\mathrm{IC}_{95 \%}=1,402-3,501\right)$, chão de concreto (OR: 2,178; $\mathrm{IC}_{95 \%}=1,217-3,889$ ), presença de ruminantes selvagens (OR: 2,998; $\mathrm{IC}_{95 \%}=1,788-5,027$ ) e época da amostragem (úmida; OR: 1,996; $\mathrm{IC}_{95 \%}=1,140-3,497$ ). Conclusões: Os resultados indicam que o BLV se encontra disseminado nas explorações no Equador. Adicionalmente, o estudo pode contribuir para a implementação de um programa de controle para a luta contra o BLV, devendo-se considerar ações de controle dos fatores de risco identificados nesta investigação.

Palavras-chave: BLV; bovino; EBL; epidemiologia; Equador; fatores de risco; gado; leucose enzoótica bovina; prevalência; ruminante; seroprevalência; soropositividade; vírus da leucemia bovina; vírus. 


\section{Introduction}

Bovine leukemia virus (BLV) is an oncogenic and lymphocytotropic Deltaretrovirus belonging to family Retroviridae, subfamily Orthoretrovirinae and genus Deltaretrovirus. It is the aetiological agent of enzootic bovine leukosis (EBL). This agent is phylogenetically related to human T-cell leukemia virus type 1 (HTLV-1; Gillet et al., 2007; Rodriguez et al., 2011). The EBL has been eradicated in many countries, mainly in the European Union (Nuotio et al., 2003; Acaite et al., 2007), but this disease is still routinely diagnosed in all LatinAmerican countries. Economic losses caused by EBL are mainly due to premature culling, reduction in milk production, and commercial restrictions with countries where official control has been implemented (Chi et al., 2002). The BLV induces chronic infection, usually with persistent lymphocytosis, as well as death due to lymphosarcoma in $5-10 \%$ of the infected animals. Mortality is high in cattle older than 4-5 years. BLV is mainly transmitted horizontally through indirect exposure to biological fluids containing previously infected B-lymphocytes. Colostral antibodies show high inhibitory activity until day 3 of lactation (Rodriguez et al., 2011; Konishi, et al., 2018).

The presence of horseflies, poorly sanitized dehorning procedures, colostrum feeding, artificial insemination, embryo transfer, blood transfer, and improper practices can lead to iatrogenic transmission and have been described as risk factors associated with BLV infection (Hopkins and DiGiacomo, 1997; Kobayashi et al., 2010). Therefore, eradication and control of BLV are based on early diagnosis culling, segregation, and elimination of carriers and improvement of farm management and biosecurity (Nuotio et al., 2003; Rodriguez et al., 2011; Ruggiero et al., 2019).

There are no EBL eradication programs in Ecuador and control measures are not widely applied. Therefore, this study aimed to establish individual and herd prevalence of BLV, which would increase visibility of the infection in this geographic area, and determine the risk factors associated with BLV seropositivity in dairy and dual-purpose cattle herds from Ecuador.

\section{Materials and Methods}

\section{Study design}

A cross-sectional study was carried out to determine BLV seroprevalence in Ecuador. Extensive production systems are mainly used for cattle farming in Ecuador (most farms do not have basic infrastructures; such as stables). Autochthonous/creole racial groups (e.g. Chusco, galapagueño, jaspeado manabita) or crossbred (e.g. Creole-Holstein, JerseyHolstein) are the most abundant cattle breeds in this country. Few farms have pure breeds such as Jersey, Holstein, Ayrshire, Charolais, Brown Swiss, among others (FAO, 2020).

In these geographical and productive conditions, the study was carried out in dairy and dual-purpose (dairy-beef) farms located in the main milk-producing provinces of Ecuador (i.e., Azuay, Chimborazo, Cotopaxi, Manabí, Santo Domingo, Pichincha, Tungurahua, and Zamora Chinchipe).

Cattle older than 6 months constituted the study population, while all cattle from dualpurpose and dairy herds from Ecuador were the target population. A herd was considered as dairy or dual-purpose when milk was collected and sold.

A herd was considered positive to BLV, and therefore, infected if at least one animal was seropositive. An epidemiological software (Win Episcope 2.0) was used to calculate the sample size. A minimum sample size of 386 herds was obtained using $50 \%$ of expected prevalence (there are no previous studies in the area), a 95\% confidence level, and an acceptable error of $5 \%$.

Due to the lack of detailed cattle herd identification information in Ecuador, the following procedure for herd selection was used: First, stratified sampling was performed, according to the number of herds in each 
province regarding the population in all of the provinces included in the study. Second, each province was divided into blocks of twentyfive square kilometers. Third, the blocks were randomly selected. Following the order provided by the software, all of the farms in the first block were visited (cluster sampling), and then all of the farms in the second block, and so on until the total number of herds per province was obtained.

A total of 386 herds were sampled. Sample size for detecting if a herd was infected was also calculated with epidemiological software using an intra-herd prevalence of 35\% (based on preliminary studies), a herd size of 10,000 (greater than the largest herd in Ecuador), and a significance level of $95 \%$, yielding a minimum sample size of 8 animals per herd. As most herds are smaller in the study area, $(>80 \%$ of the herds with $<100$ animals), sample size showed better sensitivity to detect infected herds (with the same number of samples, sensitivity is greater if herd size is smaller). Among farms with herd size of eight animals or less, all animals older than six months were sampled. This design has been used in similar studies in Ecuador (Saa et al., 2012).

\section{Serological analysis}

Blood samples $(10 \mathrm{ml})$ from each animal were collected by puncture in the caudal vein with a needle using tubes without anticoagulant (Vacutainer ${ }^{\circledR}$, Becton-Dickinson). Serum samples were stored at $-25^{\circ} \mathrm{C}$ until analyses.

Presence of antibodies to BLV was tested using a commercial blocking enzyme-linked immunosorbent assay (ELISA Ingezim BLV Compac2.0, Madrid, Spain) based on two monoclonal antibodies against viral gp51. This test allows detecting antibodies against BLV in bovine serum or milk (individual or pooled). Plates were coated with BLV gp51 and bound to the plate trough two specific monoclonal antibodies against gp51 virus protein. After adding the sample to the well, if it contains specific antibodies against the virus, they will bind to the antigen absorbed on plate. In contrast, if the sample does not contain specific antibodies, they will not bind to the antigen. Adding the substrate in the presence of peroxidase develops a colorimetric reaction. According to the manufacturer, diagnostic test sensitivity and specificity were $100 \%$, so true prevalence was considered equivalent to the apparent prevalence.

\section{Data collection}

Considering variables potentially associated with BLV infection, a structured questionnaire was completed in each herd by direct interview with the farmer. Our observations were supported with feedback from the farmers. The variables included were grouped by topics: Cattle-related data, general data about the farm, management measures, reproduction system, feeding, facilities, introduction of the infection, and animal health.

\section{Statistical analysis}

An initial selection of the explanatory variables was performed using the Chi-square test to determine the risk factors associated with infection, selecting variables associated with BLV seropositivity with $p<0.05$. Next, a Phi test was used for dichotomic variables to determine collinearity between selected explanatory variables. If Phi was $>(0.4)$, only the variable more logically associated with BLV seropositivity was retained (the $p$-values associated with Phi were $<0.001$ in all cases). On the other hand, an association between BLV seropositivity and quantitative variables was determined using a Kolmogorov-Smirnov test for independent variables (variables were selected when $p<0.05$ ). In a second step, correlations between independent quantitative variables were evaluated by an $r$ of Pearson. If $r$ was $>(0.4)$, only the variable more logically associated with BLV seropositivity was retained.

The effect of the previously selected exploratory variables on the dependent variable was investigated using a generalized estimating equation (GEE) model. The BLV seropositivity was the dependent variable, and the herd was included as a random effect. Changes in the OR greater than $20 \%$ were considered indicative of 
confounding (associations could be due to a third variable associated with both the dependent and the independent variable). The model was re-run until all of the remaining variables presented with statistically significant values (the likelihoodratio Wald's test, $p<0.05$ ), and a potential causal relationship with the dependent variable existed. The choice of the best model was based on quasi-likelihood under the independence model criterion (QIC). The statistical analysis was performed using software (SPSS v15.0). The maps were developed with a commercial software (ArcMap ${ }^{\mathrm{TM}}$ 9.3).

\section{Map design}

To obtain the probability map of BLV seropositivity occurrence in Ecuador, a model of maximum entropy ecological niche model (MaxEnt; version 3.4.1; Phillips, 2006) was used. Similarly, to determine the regions of maximum probability of prevalence, 139 notifications of seropositivity were used, distributed in two subgroups.

Nineteen independent variables with a resolution of $1 \mathrm{~km}$ sourced from WorldClim were used (Hijmans et al., 2005). The model was calibrated with a default convergence threshold, regularization of 1 , and a number of interactions of 5000. A logistic model was used to obtain values between 0 and 1 . Those variables with high weight from the 19 climatic variables were identified, and Spearman's coefficient was calculated to determine the correlation between variables. If the Spearman's Rho was $>0.6$, one of the variables was eliminated. Finally, four variables were selected (Bio1: annual mean temperature; Bio 4: seasonality of the temperature-standard deviation; Bio12: annual rainfall; and, Bio 13: rainfall in the wettest month).

The final model was evaluated using crossvalidation with $75 \%$ of the samples for training (105 notifications) and $25 \%$ for validation (34 notifications). In this way, the yields were evaluated using the area under the curve (AUC). The final model was used to generate the BLV seroprevalence map, using QGIS 2.14.

\section{Results}

A total of 2,668 serum samples from 386 herds were taken. Individual seroprevalence of BLV was $17.3 \%\left(461 / 2,668 ; \mathrm{CI}_{95 \%}=15.86-\right.$ $18.74 \%$ ), while herd prevalence was $37.8 \%$ $\left(146 / 386 ; \mathrm{CI}_{95 \%}=33.0-42.6 \%\right)$. Intra-herd prevalence ranged from 12.5 to $100 \%$ (median: $37.5 \%)$.

In the univariable analysis (Chi-squared analysis), seroprevalence was significantly higher in dairy herds $(20.4 \%)$ compared to dualpurpose herds (11.1\%). Significantly higher seropositivity was also found in crossbred cattle (23.1\%) as compared to pure breed and creole cattle jointly (14.1\%; Table 1).

Table 1. Nominal variables associated $(\mathrm{p}<0.15)$ with bovine leukemia virus (BLV) seropositivity at herd level among dairy and dual-purpose cattle herds in Ecuador.

\begin{tabular}{lccc}
\hline Variable & Category & Total (\% BLV seropositivity) & Chi-squared $\boldsymbol{p}$ \\
\hline Herd type & Dairy farms & $362(20.4)$ & $<0.001$ \\
& Dual-purpose & $99(11.1)$ & \\
Creole breed & Yes & $170(10.6)$ & $<0.001$ \\
& No & $291(27.4)$ & \\
Crossbreed & Yes & $216(23.1)$ & $<0.001$ \\
Cleanliness of facilities & No & $245(14.1)$ & $<0.001$ \\
& Good & $237(19.9)$ & $<0.001$ \\
Division of pastures & Bad & $224(15.2)$ & \\
Natural mating & Yes & $317(22.2)$ & $<0.001$
\end{tabular}




\begin{tabular}{|c|c|c|c|}
\hline \multirow[t]{2}{*}{ Artificial insemination } & Yes & $225(33.4)$ & \multirow[t]{2}{*}{$<0.001$} \\
\hline & No & $236(11.8)$ & \\
\hline \multirow[t]{2}{*}{ Synchronization of births } & Yes & $136(34.4)$ & \multirow[t]{2}{*}{$<0.001$} \\
\hline & No & $325(14.3)$ & \\
\hline \multirow[t]{2}{*}{ Colostrum used to feed calves } & Yes & $340(18.8)$ & \multirow[t]{2}{*}{0.003} \\
\hline & No & $121(14.1)$ & \\
\hline \multirow[t]{2}{*}{ Ad libitum feeding } & Yes & $116(11.6)$ & \multirow[t]{2}{*}{$<0.001$} \\
\hline & No & $345(20.7)$ & \\
\hline \multirow[t]{2}{*}{ Total absence of facilities } & Yes & $134(15.0)$ & \multirow[t]{2}{*}{0.029} \\
\hline & No & $327(18.4)$ & \\
\hline \multirow[t]{2}{*}{ Livestock chute } & Yes & $222(23.1)$ & \multirow[t]{2}{*}{$<0.001$} \\
\hline & No & $239(14.0)$ & \\
\hline \multirow[t]{2}{*}{ Milking parlor } & Yes & $206(37.9)$ & \multirow[t]{2}{*}{$<0.001$} \\
\hline & No & $255(12.0)$ & \\
\hline \multirow[t]{2}{*}{ Stables } & Yes & $209(25.2)$ & \multirow[t]{2}{*}{$<0.001$} \\
\hline & No & $252(13.7)$ & \\
\hline \multirow[t]{2}{*}{ Ground-like bed } & Yes & $103(9.4)$ & \multirow[t]{2}{*}{$<0.001$} \\
\hline & No & $358(22.7)$ & \\
\hline \multirow[t]{2}{*}{ Wood chips bed } & Yes & $8(50.0)$ & \multirow[t]{2}{*}{$<0.001$} \\
\hline & No & $453(17.1)$ & \\
\hline \multirow[t]{2}{*}{ Concrete floor } & Yes & $117(31.8)$ & \multirow[t]{2}{*}{$<0.001$} \\
\hline & No & $344(15.0)$ & \\
\hline \multirow[t]{2}{*}{ Footbaths } & Yes & $16(50.0)$ & $<0.001$ \\
\hline & No & $445(16.9)$ & \\
\hline Presence of sheep & Yes & $89(14.1)$ & 0.017 \\
\hline & No & $372(18.3)$ & \\
\hline Presence of wild ruminants & Yes & $130(29.6)$ & $<0.001$ \\
\hline & No & $331(14.8)$ & \\
\hline Adjacent cattle farms & Yes & $222(19.4)$ & 0.011 \\
\hline & No & $239(15.7)$ & \\
\hline Purchase of animals & Yes & $67(26.9)$ & $<0.001$ \\
\hline & No & $394(16.3)$ & \\
\hline Replacement of animals & Yes & $319(21.6)$ & $<0.001$ \\
\hline & No & $142(11.9)$ & \\
\hline Purchase and replacement of animals & Yes & $157(13.9)$ & $<0.001$ \\
\hline & No & $304(19.8)$ & \\
\hline Disinfection of the umbilical cord & Yes & $164(19.7)$ & 0.025 \\
\hline & No & $297(16.2)$ & \\
\hline Deworming of calves & Yes & $320(19.4)$ & $<0.001$ \\
\hline & No & $141(13.9)$ & \\
\hline Deworming of adults & Yes & $313(18.9)$ & 0.005 \\
\hline & No & $148(14.6)$ & \\
\hline Quarantine & Yes & $121(22.3)$ & $<0.001$ \\
\hline & No & $340(16.0)$ & \\
\hline Andean region & Yes & $316(21.7)$ & $<0.001$ \\
\hline & No & 145 (11.9) & \\
\hline Sampling season & Wet & $87(15.5)$ & $<0.001$ \\
\hline & Dry & $374(34.7)$ & \\
\hline
\end{tabular}


BLV seroprevalence significantly increased in herds with more than 40 animals (20.6 vs. $13.3 \%$ in herds $<40$ animals). The distribution of BLV seropositivity among provinces is shown in Table 2.

Table 2. Distribution of bovine leukemia virus (BLV) herd seroprevalence by province in Ecuador.

\begin{tabular}{lccc}
\hline Province & \multicolumn{2}{c}{ Bovine leukemia virus status } & Total \\
\hline & $\begin{array}{c}\text { Positive* } \\
(\%)\end{array}$ & $\begin{array}{c}\text { Negative } \\
(\%)\end{array}$ & \\
Azuay & $31(53.4)$ & $27(46.6)$ & 58 \\
Chimborazo & $14(31.8)$ & $30(68.2)$ & 44 \\
Cotopaxi & $22(57.9)$ & $16(42.1)$ & 38 \\
Manabi & $25(23.6)$ & $81(76.4)$ & 106 \\
Pichincha & $26(49.1)$ & $27(50.9)$ & 53 \\
Santo Domingo & $8(22.9)$ & $27(77.1)$ & 35 \\
Tungurahua & $7(22.6)$ & $24(77.4)$ & 31 \\
Zamora Chinchipe & $13(61.9)$ & $8(38.1)$ & 21 \\
Total & $146(37.8)$ & $240(62.2)$ & 386 \\
\hline
\end{tabular}

*Herds with at least one seropositive animal.

The highest seroprevalence $(>50 \%)$ was found in Azuay, Cotopaxi, and Zamora Chinchipe provinces. Figures 1 and 2 show prevalence and distribution of BLV seropositivity in Ecuador at individual and herd level, respectively. Distribution of BLV seropositivity was widespread. Infection was present in all provinces, ranging from $22.6 \%$ in Tungurahua to $61.9 \%$ in Zamora Chinchipe.
Results from the univariable analysis are shown in Tables 1 and 3. No confounding factors or potentially relevant interactions between independent variables were observed in the final model. The GEE model included sampling season (wet), artificial insemination, concrete floor, and presence of wild ruminants as risk factors associated with BLV seropositivity (Table 4).

Rainfall in the wettest month (46.9\%), temperature (23.4\%), annual precipitation (15.3), and temperature seasonality (14.4\%) were identified as climatic factors with the greatest predictive value for occurrence of BLV seropositivity in Ecuador. The AUC of the data for training was 0.97, while that for validation was $(0.888)$. Thus, the model agreed exceptionally well for both training and validation data.

The results show that probability of seropositivity increases for annual rainfall between 750 to $900 \mathrm{~mm}$, with high monthly variations (rainfall in the wettest month between 75 to $120 \mathrm{~mm}$ ). Mean annual temperature was between 10 to 15 degrees, ranging between 6.2 and 7.5 degrees (standard deviation; Figures 3 and 4).

Table 3. Quantitative variables selected in the univariable analysis for bovine leukemia virus (BLV) seropositivity in dairy and dual-purpose cattle farms from Ecuador $(\mathrm{p}<0.05)$.

\begin{tabular}{lcccccccc}
\hline Variable & Mean & Median & Mode & Standard error & Min. $^{\mathbf{1}}$ & Max. $^{\mathbf{2}}$ & K-S Z $^{\mathbf{3}}$ & $\boldsymbol{p}$ \\
\hline Animal age (months) & 46.2 & 48 & 48 & 31.3 & 3 & 180 & 3.60 & $<0.001$ \\
Number of cattle & 82.8 & 40 & 60 & 146.7 & 2 & 1600 & 3.29 & $<0.001$ \\
Number of cows & 24.1 & 13 & 5 & 30.8 & 0 & 230 & 3.67 & $<0.001$ \\
Number of calves & 19.0 & 9 & 3 & 38.0 & 0 & 500 & 2.15 & $<0.001$ \\
Farm size (ha) & 110.6 & 30 & 40 & 305.8 & $<1$ & 3200 & 3.34 & $<0.001$ \\
Hectares used by cattle & 82.4 & 25 & 30 & 235.0 & $<1$ & 3200 & 3.04 & $<0.001$ \\
Terrain slope & 16.1 & 15 & 0 & 15.2 & 0 & 60 & 1.42 & 0.036 \\
Altitude (m) & 1639.7 & 1767.07 & 200 & 1348.4 & 2.5 & 3914.8 & 5.67 & $<0.001$ \\
Calf age at weaning (months) & 4.0 & 5 & $<1$ & 3.4 & $<1$ & 88 & 4.59 & $<0.001$ \\
Annual mortality rate of adults & 4.4 & 1 & $<1$ & 7.7 & $<1$ & 45 & 3.94 & $<0.001$ \\
\hline
\end{tabular}

${ }^{1}$ Minimum value. ${ }^{2}$ Maximum value. ${ }^{3}$ Kolmogorov - Smirnov Z. 


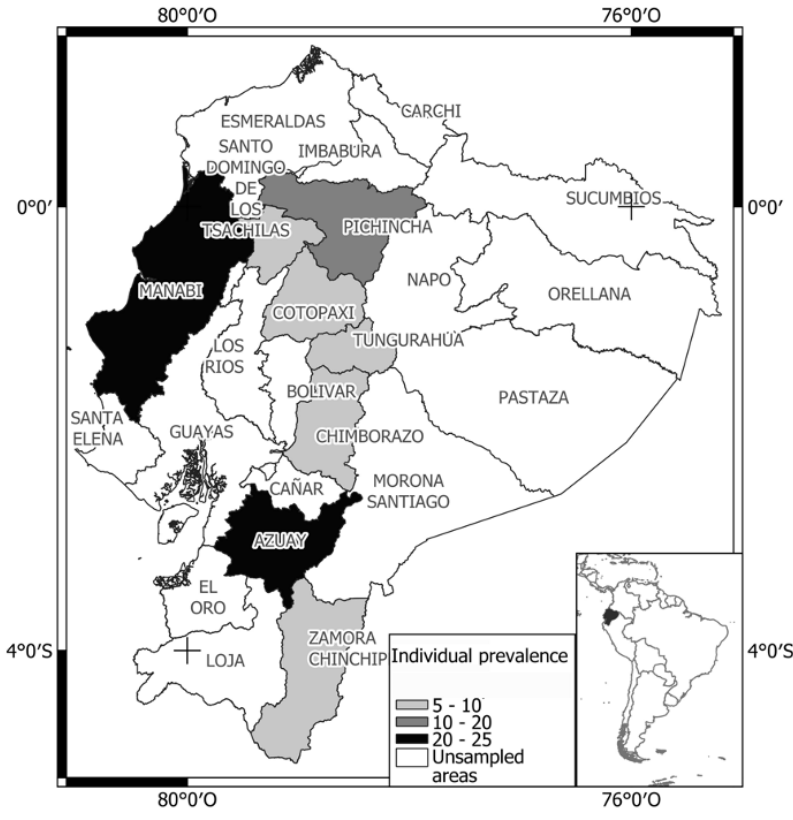

Figure 1. Animal-level seroprevalence of bovine leukemia virus (BLV) in several Ecuador provinces.

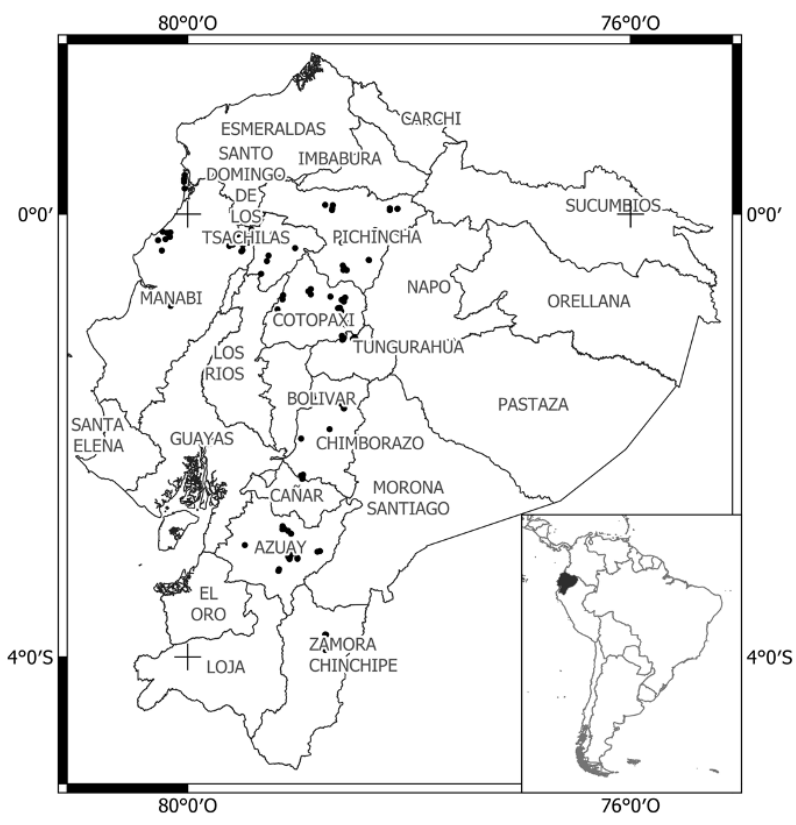

Figure 3. Spatial distribution of 139 bovine leukemia virus (BLV) cases (seroprevalence). Black dots indicate BLV seropositive cases.

Rev Colomb Cienc Pecu 2021; 34(3, Jul-Sep):177-188 https://doi.org/10.17533/udea.rccp.v34n3a01

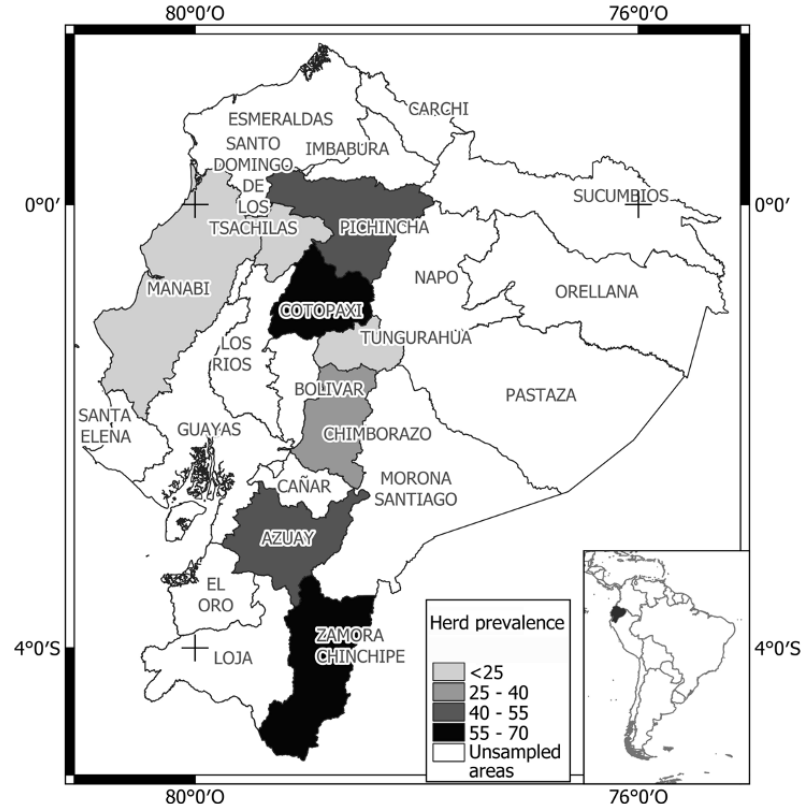

Figure 2. Herd-level seroprevalence of bovine leukemia virus (BLV) in several Ecuador provinces.

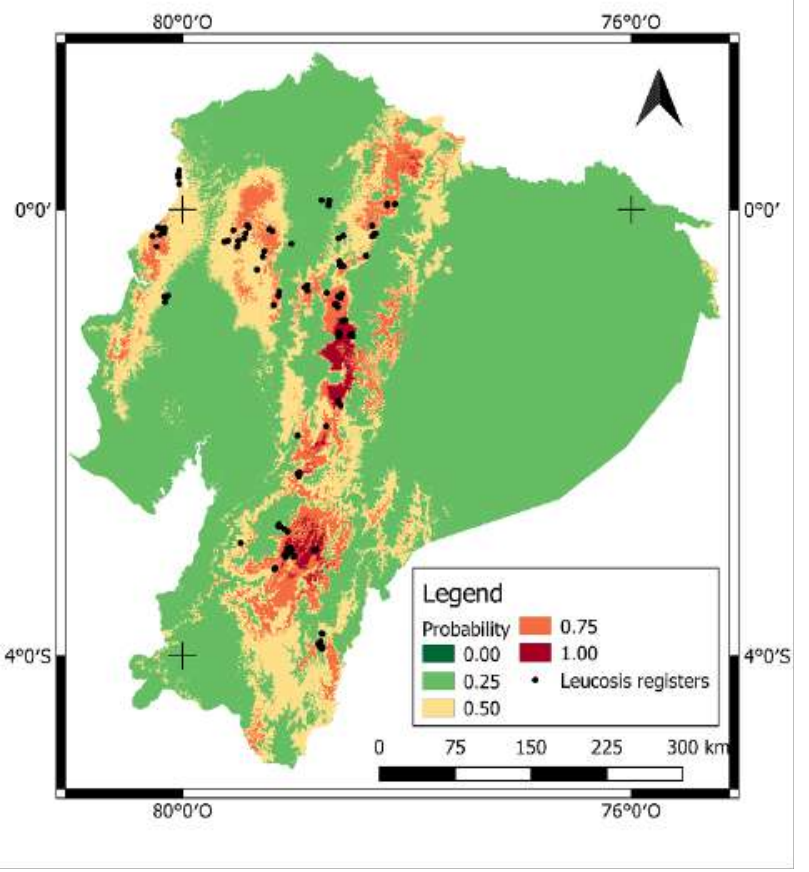

Figure 4. Probability map of bovine leukemia virus (BLV) seropositivity occurrence in Ecuador. The darkest colors show increased probability of seropositivity occurrence, while the black dots indicate seropositive of BLV cases. 
Table 4. GEE model including the risk factors significantly $(\mathrm{p}<0.05)$ associated with bovine leukemia virus (BLV) seropositivity in dairy and dual-purpose herds from Ecuador (2008-2011).

\begin{tabular}{lccccc}
\hline Variables & Category & n & BLV seropositivity (\%) & OR & 95\% CI \\
\hline Sampling season & Wet & 1,707 & 24.3 & 1.996 & $1.140-3.497$ \\
& Dry & 961 & 13.4 & & \\
Artificial Insemination & Yes & 674 & 33.4 & 2.215 & $1.402-3.501$ \\
\multirow{2}{*}{ Concrete floor } & No & 1,994 & 11.8 & & \\
\multirow{2}{*}{ Presence of wild ruminants } & Yes & 368 & 31.8 & 2.178 & $1.217-3.889$ \\
& No & 2,300 & 15.0 & & \\
& Yes & 439 & 29.6 & 2.998 & $1.788-5.027$ \\
\hline
\end{tabular}

OR: Odds Ratio; CI: Confidence interval.

*OR of the reference category was 1 in all cases. The QIC of the model is 2,218.

\section{Discussion}

This is the first nationwide survey to estimate the prevalence of antibodies and determine the risk factors associated with BLV seropositivity in Ecuador. Individual prevalence was $17.3 \%$, agreeing with those previously reported in Brazil (7.6-50\%) and Argentina (32.8\%; Trono et al., 2001; Amoril et al., 2009; Rodriguez et al., 2011). Herd prevalence was 37.8\%, which is lower than that described in Argentina (84\%; Trono et al., 2001; Gutierrez et al., 2011). Our results are consistent with the herd prevalence of BLV (34 to 94\%) found in Colombia, Venezuela, Chile, Uruguay and US (Alfonso et al., 1998; Rodriguez et al., 2011; LaDronka et al., 2018). However, herd prevalence could be underestimated because it is possible that herds with intra-herd prevalence lower than $35 \%$ were not detected as positive.

The results indicate that BLV infection is widespread among dairy and dual-purpose cattle herds in Ecuador. This may be due to poor management factors and the absence of eradication programs in this country. Another contributing factor for the high distribution of BLV infection could be the abundance of horseflies and blood-sucking insects present in the farms, especially in the warm wet season (Bech-Nielsen et al., 1978; Chi et al., 2002; Kobayashi et al., 2014). Unfortunately, no routine control against horseflies is generally practiced in Ecuador.
Associations with BLV seropositivity only by univariable analysis (such as breed) or type of herd can be caused by other factors - not the variable itself, and have been included in the results section just as descriptive results. The GEE model included AI, concretefloor, presence of wild ruminants, and season of sampling. In Ecuador, AI (OR: 2.215; $\mathrm{C}_{\mathrm{I} 95 \%}=1.402-3.501$ ) usually implies rectal palpation (to test if the cow is already pregnant and if the reproductive tract is in good condition for an adequate pregnancy), which is usually performed without changing gloves and sleeves between animals. Although vertical transmission has been reported for leukosis virus, it is more probably that the high prevalence where AI is used be due to the mentioned inadequate practices. Our results are consistent with previous reports by Divers et al., 1995; Rodriguez et al., 2011; and Kobayashi et al., 2014.

Concrete floor was also a risk factor for BLV seropositivity in the area (OR: 2.178; $\mathrm{CI}_{95 \%}=$ 1.217-3.889). This floor type is more abrasive than other floors in the area (e.g., pastures, ground, wood shaving), so animals could be at a higher risk of suffering wounds that would be a gateway for BLV. Therefore, cattle are enclosed, and contact with other animals is increased (Carbonero et al., 2011; Saa et al., 2012).

Improper handling practices, such as use of the same hypodermic needles for different 
cows, can lead to iatrogenic transmission. These practices have been described as risk factors for other infections in Ecuador (Sargeant et al., 1997; Saa et al., 2012; Carbonero et al., 2015). In addition, close contact during milking may favor BLV transmission.

Presence of wild ruminants in grazing areas was another next factor included in the model (OR: 2.998; $\left.\mathrm{CI}_{95 \%}=1.788-5.027\right)$. Presence of wild ruminants was considered positive (yes; $16.8 \% ; 149 / 386$ ) if the farmer affirmed that wild ruminants had been observed in the farm surroundings. Species belonging to Mazama and Odocoileus genus are the most common wild deer species in the area (Tirira, 2007). Chomel et al., (1994) reported that black-tailed deer (Odocoileus hemionus) developed BLV infection under experimental conditions. However, Yokoi et al. (2009) did not find evidence of BLV infection in domestic sika deer (Cervus nipponyesoensis) in Japan. Although the role of wildlife, particularly wild ruminants, in BLV epidemiology remains unclear, this study suggests that they could play a role in the epidemiology of BLV infection. More studies are needed to clarify this point. Disease transmission between domestic and wild animals frequently results in severe consequences for the health of both species (Yokoi et al., 2009; Martin et al., 2011).

Sampling season (i.e., wet) was the other risk factor included in the model (OR: 1.996; $\mathrm{CI}_{95 \%}=$ 1.140-3.497). Other authors have described that BLV follows a seasonal pattern, and it is related to abundant horseflies and hematophagous insects during summer, being equivalent to the hot and wet season in the sampled areas of Ecuador. The role of different bloodsucking insects in the natural transmission of BLV is well known (Bech-Nielsen et al., 1978; Hopkins et al., 1997). In this sense, high presence of horseflies has been previously associated with BLV seropositivity (Kobayashi et al., 2010; 2014). The fact that one of the frequent signs of BLV is lymphocytosis increases the probability of infection (Bech-Nielsen et al., 1978).
In conclusion, these results indicate that BLV infection is widespread in dairy and dualpurpose cattle herds in Ecuador. The BLV seroprevalence is significantly influenced by AI, use of concrete floors, sampling season (wet), and presence of wild ruminants. Considering the risk factors determined by the model, our results suggests that a control program to fight against BLV infection should be implemented in Ecuador (Hopkins et al., 1997).

\section{Declarations}

\section{Acknowledgments}

We would like to thank the farmers who participated in the study, and the people at Laboratorio de Sanidad, Reproducción Animal y Zoonosis (LABSA).

\section{Funding}

This study was supported by Universidad Técnica Particular de Loja.

\section{Conflict of interest}

The authors declare they have no conflicts of interest with regard to the work presented in this report.

\section{Author contributions}

Luis Rodrigo Saa and Alfonso Carbonero participated in the design and coordination of the study, performed the data collection and statistical analyses, drafted the manuscript and performed the serological diagnoses. Luz María Castro, Lucía Guzmán and Natacha Fierro participated in the design of the study and reviewed the data analyses performed by Luis Rodrigo Saa, and Alfonso Carbonero. Fabián Reyes helped revise the data and helped draft the manuscript and maps. All of the authors read and approved the final manuscript. 


\section{References}

Acaite J, Tamosiunas V, Lukauskas K, Milius J, Pieskus J. The eradication experience of enzootic bovine leukosis from Lithuania. Prev Vet Med 2007; 82(1-2):83-89. DOI:

https://doi.org/10.1016/j.prevetmed.2007.05.010

Alfonso R, Almansa JE, Barrera JC. Serological prevalence and evaluation of the risk factors of bovine enzootic leukosis in the Bogotá Savannah and the Ubaté and Chiquinquirá Valleys. Colombia Rev Sci Tech 1998; 17(3):723-32. DOI: https://dx.doi.org/10.20506/rst.17.3.1126

Amoril JG, Samara SI, Tarabla HD, Camargos MF, Furtado CCV. Seroprevalence and risk factors for bovine leukemia virus infection in cattle of Goiás, Brazil Vet Immunol Immunop 2009; 128(1):333-334. DOI: https://doi.org/10.1016/j.vetimm.2008.10.263

Bech-Nielsen S, Piper CE, Ferrer JF. Natural mode of transmission of the bovine leukemia virus: role of bloodsucking insects. Am J Vet Res 1978; 39:1089-1092. PMID: 209707.

Carbonero A, Guzmán LT, Montaño K, Torralbo A, Arenas-Montes A, Saa LR Coxiella burnetii seroprevalence and associated risk factors in dairy and mixed cattle farms from Ecuador. Prev Vet Med 2015; 118(4):427-435. DOI: https://doi.org/10.1016/j.prevetmed.2015.01.007

Carbonero A, Saa LR, Jara DV, GarcíaBocanegra I, Arenas A, Borge C, Perea A, Seroprevalence and risk factors associated to Bovine Herpesvirus 1 (BHV-1) infection in nonvaccinated dairy and dual-purpose cattle herd in Ecuador. Prev Vet Med 2011; 100(1):84-88. DOI: https://doi.org/10.1016/j.prevetmed.2011.03.006

Chi J, Van Leeuwen JA, Weersink A, Keefe GP. Direct production losses and treatment costs from bovine viral diarrhoea virus, bovine leukosis virus, Mycobacterium avium subspecies paratuberculosis, and Neospora caninum. Prev Vet Med 2002; 55(2):137-153. DOI: https://doi.org/10.1016/s0167-5877(02)00094-6
Chomel BB, Carniciu ML, Kasten RW, Castelli PM, Work TM, Jessup DA. Antibody prevalence of eight ruminant infectious diseases in California mule and black-tailed deer (Odocoileus hemionus). J Wild Dis 1994; 30(1):51-59. DOI: https://doi.org/10.7589/0090-3558-30.1.51

Divers TJ, Bartholomew RC, Galligan D, Little C. Evidence for transmission of bovine leukemia virus by rectal palpation in a commercial dairy herd. Prev Vet Med 1995; 23(3-4):133-141. DOI: https://doi.org/10.1016/0167-5877(95)00464-8

FAO. Sistema de Información sobre la Diversidad de los Animales Domésticos (DAD-IS); [9 de Julio de 2020]. URL: https://www.fao.org/dad-is/browse-by-countryand-species/es/

Gillet N, Florins A, Boxus M, Burteau C, Nigro A, Vandermeers F, Balon H, Bouzar A, Defoiche J, Burny A, Reichert M, Kettmann R, Willems L. Mechanisms of leukemogenesis induced by bovine leukemia virus: prospects for novel anti-retroviral therapies in human. Retrovirology 2007; 4(1):18. DOI: https://doi.org/10.1186/1742-4690-4-18

Gutierrez G, Alvarez I, Politzki R, Lomónaco M, Dus Santos MJ, Rondelli F, Fondevila, F, Trono K. Natural progression of bovine leukemia virus infection in Argentinean dairy cattle. Vet. Microbiol 2011; 151(3-4):255-263. DOI: https://doi.org/10.1016/j.vetmic.2011.03.035

Hijmans RJ, Cameron SE, Parra JL, Jones PG, Jarvis A. Very high-resolution interpolated climate surfaces for global land areas. Int J Climatol 2005; 25(15):1965-1978. DOI: https://doi.org/10.1002/joc.1276

Hopkins SG, DiGiacomo RF. Natural transmission of bovine leukemia virus in dairy and beef cattle. Vet Clin North Am Food Anim Pract 1997; 13(1):107-28. DOI: https://doi.org/10.1016/s0749-0720(15)30367-4

Kobayashi S, Hidano A, Tsutsui T, Yamamoto T, Hayama Y, Nishida T, Muroga N, Konishi M, Kameyama K, Murakami K. Analysis of risk factors associated with bovine leukemia 
virus seropositivity within dairy and beef breeding farms in Japan: A nationwide survey. Res Vet Sci 2014; 96(1):47-53. DOI: https://dx.doi.org/10.1016/j.rvsc.2013.11.014

Kobayashi S, Tsutsui, T, Yamamoto T, Hayama Y, Kameyama K, Konishi M. Risk factors associated with within-herd transmission of bovine leukemia virus on dairy farms in Japan. BMC Vet Res 2010; 6(1):1. DOI: https://doi.org/10.1186/1746-6148-6-1

Konishi M, Ishizaki H, Kameyama K, Murakami K, Yamamoto T. The effectiveness of colostral antibodies for preventing bovine leukemia virus (BLV) infection in vitro. BMC Vet Res 2018; 14(1):419. DOI: https://doi.org/10.1186/s12917-018-1724-5

LaDronka R, Ainsworth S, Wilkins $\mathrm{M}$, Norby B, Byrem T, Bartlett P, Prevalence of bovine leukemia virus antibodies in US dairy cattle. Vet Med In 2018; 2018(11):1-8. DOI: https://doi.org/10.1155/2018/5831278

Martin C, Pastoret P, Brochier B, Humblet M, SaegermanC.Asurveyofthetransmitionofinfectous diseases/infections between wild and domestic ungulates in Europe. Vet Res 2011; 42(1):70. DOI: https://doi.org/10.1186/1297-9716-42-70

Nuotio L, Rusanen H, Sihvonen L, Neuvonen E. Eradication of enzootic bovine leukosis from Finland. Prev Vet Med 2003; 59(1-2):43-49. DOI: https://doi.org/10.1016/s0167-5877(03)00057-6

Rodriguez SM, Florins A, Gillet N, Brogniez A, Sánchez-Alcaraz MT, Boxus M, Boulanger F, Gutierrez G, Trono K, Alvarez I, Vagnoni L, Willems L. Preventive and therapeutic strategies for bovine leukemia virus: lessons for HTLV. Viruses 2011; 3(7):1210-1248. DOI: https://doi.org/10.3390/v3071210
Ruggiero VJ, Norby B, Benitez OJ, Hutchinson H, Sporer KR, Droscha C, Swenson CL Bartlet PC. Controlling bovine leukemia virus in dairy herds by identifying and removing cows with the highest proviral load and lymphocyte counts. J Dairy Sci 2019; 102(10):9165-9175. DOI: https://doi.org/10.3168/jds.2018-16186

Saa LR, Perea A, García-Bocanegra I, Arenas AJ, Jara DV, Ramos R, Carbonero A. Seroprevalence and risk factors associated with bovine viral diarrhea virus (BVDV) infection in non-vaccinated dairy and dual purpose cattle herds in Ecuador. Trop Anim Health Prod 2012; 44(3):645-649. DOI: http://doi.org/10.1007/s11250-011-9948-4

Sargeant JM, Kelton DF, Martin SW, Mann ED. Association between farm management practices, productivity, and bovine leukemia virus infection in Ontario dairy herds. Prev Vet Med 1997; 31(3-4):211-221. DOI: https://doi.org/10.1016/S0167-5877(96)01140-3

Tirira D. Guía de campo de los mamíferos del Ecuador, 1st ed. Quito: Murciélago Blanco; 2007.

Trono K, Pérez-Filgueira D, Duffy S, Borca M, Carrillo C. Seroprevalence of bovine leukemia virus in dairy cattle in Argentina: comparison of sensitivity and specificity of different detection methods. VetMicrobiol2001;83(3):235-248.DOI: https://doi.org/10.1016/s0378-1135(01)00420-5

Yokoi K, Okazaki H, Inahara K, Hatama S. Prevalence of eight bovine viruses in sika deer (Cervus nippon yesoensis) in Japan. Vet Rec 2009; 165(25):754-755. DOI: https://doi.org/10.1136/vr.165.25.754 